\title{
Kwalitatieve ranglijsten van medische opleidingen zijn zinvol
}

\author{
C.P.M. van der Vleuten
}

Ranglijsten ("league tables") van onderwijsinstellingen zijn heel gebruikelijk in bijvoorbeeld de VS. In Nederland zijn wij dit niet gewend. Onlangs is de nodige maatschappelijke discussie ontstaan over het gebruik van toetsresultaten en rendementen voor de onderlinge vergelijking van middelbare scholen. In het hoger onderwijs kennen wij de jaarlijkse ElsevierNIPO-beoordelingen en de oordelen van studenten in de Keuzegids hoger onderwijs (www.keuzegids.org/). In het nieuwe accreditatieproces van ons hoger onderwijs zullen eindoordelen openbaar worden gemaakt. Dit lijkt mij juist: kwaliteit van onderwijs moet verantwoord worden, net zoals bij alle andere maatschappelijke bestedingen.

Een kwaliteitsoordeel moet gebaseerd zijn op een geldige meting. Geldigheid wordt vaak uitgedrukt als mate van betrouwbaarheid en van validiteit. Deze termen slaan op kwantitatieve metingen en niet op kwalitatieve. Nu maak ik geen wezenlijk onderscheid tussen kwantitatieve en kwalitatieve ranglijsten. Voor beide bestaan dezelfde eisen, maar wij hanteren verschillende termen en methoden voor hun verantwoording. Voor kwalitatieve gegevens wordt gesproken over de "geloofwaardigheid" van de gegevens en daar bestaan talloze methoden voor. ${ }^{1}$

Hoe goed zijn bestaande ranglijsten? Uit de vergelijkbare resultaten van aaneengesloten jaren in de Elsevier-NIPO-enquêtes over een periode van ongeveer 10 jaar blijkt de reproduceerbaarheid van deze gegevens. ${ }^{2}$ En uit de geleidelijke verandering van de uitslagen blijkt dat plaatsverschuiving in de ranglijsten wel degelijk mogelijk is en ook geregistreerd wordt. Voor deze veranderingen zouden goede onderwijskundige verklaringen gegeven kunnen worden, maar dat voert op deze plaats te ver. De enquêtes betreffen een kwantitatieve meting, maar een oordeel dat tot stand komt op grond van een intensieve visitatie of doorlichting en dat op narratieve wijze wordt beschreven, kan even geldig zijn als een kwantitatieve meting. Uiteraard kunnen ongeldige metingen onjuiste beoordelingen opleveren, waardoor ze niet verdedigbaar zijn. Maar het kán wel.

Geldige gegevens kunnen onverantwoord gebruikt worden. In de toetsliteratuur gelden hiervoor de volgende adagia: één meting is geen meting en geen enkele methode is zaligmakend. Echte zware beslissingen zoals het radicaal veranderen van het onderwijsprogramma of het afwijzen van een accreditatie, zijn gebaat bij meerdere metingen en bij consistentie van de uitkomsten met betrekking tot verschillende informatiebronnen. In de praktijk zal het gebruik van de data niet altijd even verantwoord zijn. Maar een verantwoording van de kwaliteit van medische opleidingen is absoluut noodzakelijk. Juist door deze verantwoording, zoals in de visitaties, is in de afgelopen decennia veel kwaliteitswinst geboekt in alle medische opleidingen. Meer competitie om de aankomende geneeskundestudent, bijvoorbeeld op grond van ranglijsten, is een goede zaak. Zo kan kwaliteit duidelijk worden. 


\section{Literatuur}

1. Lincoln YS, Guba EA, editors. Naturalistic inquiry. Beverly Hills, CA: Sage; 1985.

2. Scherpbier AJJA. Het medisch onderwijs en het NVMO-congres. Waar staan we en hoe moeten we verder? Tijdschrift voor Medisch Onderwijs 2004;23:172-7.
Correspondentieadres:

Prof. dr. C.P.M. van der Vleuten, Universiteit van Maastricht, Capaciteitsgroep Onderwijsontwikkeling en -research, Postbus 616, 6200 MD Maastricht.

Belangenconflict: geen gemeld.

Financiële ondersteuning: geen gemeld.

\section{De auteur:}

Prof. dr. C.P.M. van der Vleuten, onderwijskundige, Capaciteitsgroep Onderwijsontwikkeling en -research, Postbus 616, 6200 MD Maastricht.

\section{Summary}

Benchmarking lists are indicators of the quality of medical curricula. The measurement on which a list in order of merit is based must of course have validity, but this is generally the case. The irresponsible use of ranking lists is to be deplored, but that does not constitute a reason not to publish them. More competition in attracting the aspirant medical student, for example on the basis of ranking lists, would be a good thing. This can contribute to making the quality more visible. Lists in order of quality are therefore a useful aid to assist the aspirant student in choosing a school. (Van der Vleuten CPM. Qualitative ranking of medical curricula is useful. Dutch Journal of Medical Education 2006;25(5):235-236.) 